\title{
Antimicrobial Resistance and Molecular Characterization of Salmonella Enterica Serotypes Isolated from Poultry Sources in Brazil
}

\section{-Author(s)}

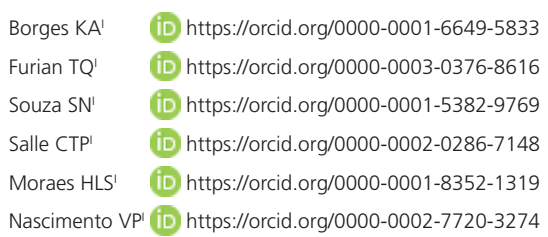

Centro de Diagnóstico e Pesquisa em Patologia Aviária (CDPA), Faculdade de Veterinária, Universidade Federal do Rio Grande do Sul (UFRGS).

\section{Mail Address}

Corresponding author e-mail address Karen Apellanis Borges

Av. Bento Gonçalves 8824, Porto Alegre, RS CEP 91540-000, Brazil.

Phone: +55 5133086138

Email: karen.borges@ufrgs.br

\section{- Keywords}

Antibiotic susceptibility, genetic virulence, chicken, salmonellosis, serovars.

\section{ABSTRACT}

Salmonella spp. remain among the most important agents of foodborne diseases worldwide. The importance of Salmonella spp. in public health is linked to their wide range of antimicrobial resistance and to their pathogenicity and virulence in both human and animal hosts. The aim of this study was to determine the antimicrobial resistance patterns for Salmonella serotypes isolated from poultry sources in Brazil and to detect virulence-associated genes and verify their association with specific serotypes. A total of 163 strains of Salmonella enterica isolated from poultry sources in Southern Brazil were selected, and each belonged to one of 11 different serotypes. They were tested against ten antibiotics and examined for the presence of 26 virulence-associated genes by PCR. S. Typhimurium, S. Bredeney, S. Schwarzengrund and S. Tennessee showed the highest overall resistance rates. Approximately $18 \%$ of Salmonella strains were classified as multidrug-resistant strains. Our results indicate associations between antimicrobial resistance and specific serotypes. Most of the investigated genes presented a high frequency and a regular distribution, regardless of the serotype. Eight genes are positively or negatively associated with at least one serotype. The observed associations between antimicrobial resistance and specific serotypes are useful in developing specific control and treatment measures for each serotype. Despite the virulence genes being evenly distributed among the serotypes, some of these genes are associated with specific serotypes, and sefA, sopEand IpfA were selected as possible markers of Salmonella serotypes.

\section{INTRODUCTION}

Salmonella spp. remain one of the main pathogens responsible for foodborne disease worldwide, and salmonellosis outbreaks are commonly associated with the consumption of poultry and poultryderived products (Centers for Disease Control, 2015; European Food Safety Authority 2017b; Brasil, 2018). In the US, Salmonella serotypes are responsible for approximately 34\% of reported infections (Centers for Disease Control, 2015). In Europe, the authorities reported Salmonella as the second most important agent of foodborne diseases, with more than 94,530 salmonellosis cases (European Food Safety Authority, 2017b). In Brazil, Salmonella is responsible for more than $30 \%$ of foodborne disease, according to the Brazilian Ministry of Health (Brasil, 2018).

For human salmonellosis cases, S. Enteritidis, S. Typhimurium (including its monophasic variant), S. Infantis, S. Derby, S. Newport, S. Heidelberg, S. Schwarzengrund and $S$. Javiana are the main serotypes isolated in humans worldwide (Robinsom, 2013; Capalonga et al., 
Borges KA, Furian TQ, Souza SN, Salle CTP, Moraes HLS, Nascimento VP

\section{Antimicrobial Resistance and Molecular Characterization of Salmonella Enterica Serotypes Isolated from Poultry Sources in Brazil}

2014; Centers for Disease Control, 2015; European Food Safety Authority, 2017b). S. Enteritidis and S. Typhimurium (including its monophasic variant) are also frequently isolated from poultry. In addition, S. Infantis, S. Heidelberg, S. Kentucky, S. Mbandaka and $S$. Senftenberg are among the most isolated serotypes (Brasil, 2008; Foley \& Lynne 2008; European Food Safety Authority, 2017b).

The importance of Salmonella spp. in public health is not only due to the high frequency of salmonellosis outbreaks but also because of the wide range of antimicrobial resistance that this microorganism presents (Tondo \& Ritter 2012). Recent studies have demonstrated increasing resistance of Salmonella strains isolated from humans and animals to the most commonly used antibiotics (European Food Safety Authority, 2017a). Recently, many studies in this area have occurred because the resistance of Salmonella in animal food products may present the potential to be transmitted to humans through the food chain (Wang et al., 2013). According to the US Food and Drug Administration, the use of antibiotic in foodproducing animals in the United States has increased approximately $20 \%$ between 2009 and 2013. Less than $30 \%$ of antibiotics sold for veterinary use were exclusively intended for therapeutic treatments (Food and Drug Administration, 2014). In 2016, 60\% of the domestic sales of all antimicrobials approved for use in food production corresponded to the medically important antimicrobials (Food and Drug Administration, 2017). Resistance has appeared since the introduction of antimicrobial agents in medical and veterinary areas. However, the resistance of some microorganisms, such as Salmonella spp. and Campylobacter jejuni, might have started in food-producing animals (Koluman \& Dikici 2013). Multidrug-resistant strains of Salmonella spp. are associated with increased hospitalization as well as deaths and the cost of treatment (World Health Organization, 2011a). The emergence of multidrugresistant Salmonella has aroused the attention of governments all over the world (Brasil, 2012; PulidoLandínez et al., 2014; Proroga et al., 2015; European Food Safety Authority, 2017a; National Antimicrobial Resistance Monitoring System for Enteric Bacteria, 2017). Therefore, monitoring Salmonella resistance in the poultry chain is essential due to the potential spread of antimicrobial-resistant Salmonella isolates to humans (Wang et al., 2013).

The way that the pathogen adapts to the conditions inside the host depends on the virulence of the strain (Madigan et al., 2010). For many pathogens, virulence is conferred by a single region of the genome. However, Salmonella pathogenesis and its interaction with the host are a complex and multifactorial phenomenon that depends on several virulence factors (Wallis \& Galyov, 2000; Skyberget al., 2006;). These factors are encoded by many virulenceassociated genes that are distributed along its chromosome and/or in mobile genetic elements such as plasmids (Wallis \& Galyov, 2000). Some virulence factors are related to the components of the bacterial structure such as fimbriae and play an important role in the virulence of the strains (Clouthier et al., 1993). Salmonella Pathogenicity Islands (SPI) are large genetic elements with pathogenic properties (Hacker \& Carniel, 2001). SPI-1 encodes the components of a Type III Secretion System (TTSS), a complex protein secretion system, and other proteins required for the invasion of non-phagocytic cells and the activation of the inflammatory response (de Jong et al., 2012; Wisner et al., 2012). The islands are also involved in Salmonella recognition and multiplication within macrophages, in iron metabolism, and in endotoxin production (Álvarez, 2007).

In this context, the aim of this study was to determine the antimicrobial resistance patterns for different Salmonella serotypes isolated from poultry sources and to detect virulence-associated genes and verify their association with specific serotypes.

\section{MATERIALS AND METHODS}

\section{Bacterial strains}

For this study, 163 strains of S. enterica were isolated from poultry sources, and they belonged to 11 different serotypes in total. The following serotypes were included: S. Enteritidis $(n=70), S$. Heidelberg $(n=49)$, S. Hadar $(n=14)$, S. Typhimurium $(n=8), S$. Anatum $(n=5), S$. Bredeney $(n=5), S$. Agona $(n=4), S$. Tennessee ( $n=3)$, S. Infantis ( $n=2)$, S. Brandenburg ( $n=2)$ and $S$. Schwarzengrund $(n=1)$. Strains were previously serotyped by the Oswaldo Cruz Institute Foundation (Fiocruz, Brazil). The bacterial isolates were kept frozen at $-80{ }^{\circ} \mathrm{C}$ in brain heart infusion $(\mathrm{BHI})$ broth $\left(\mathrm{Oxoid}^{\circledR}\right.$, United Kingdom) and were supplemented with 15\% glycerin (Synth ${ }^{\circledR}$, Brazil).

\section{Antimicrobial susceptibility test}

Antimicrobial susceptibility was determined by the disc diffusion method according to the Clinical and Laboratory Standards Institute (Clinical and 
Borges KA, Furian TQ, Souza SN, Salle CTP, Moraes HLS, Nascimento VP

\section{Antimicrobial Resistance and Molecular Characterization of Salmonella Enterica Serotypes Isolated from Poultry Sources in Brazil}

\section{Statistical analysis}

Chi-square $(\chi 2)$ and Fisher's tests were used to analyse the susceptibility of the strains to the different antimicrobials tested, to compare the resistances and to analyse the presence of virulence genes among Salmonella serotypes. Discriminant analysis was used to build decision tree and identify possible serotype marker genes.

\section{RESULTS}

\section{Antimicrobial susceptibility test}

The antimicrobial resistances of Salmonella strains regardless of the serotype are described in Figure 1. Among the 163 analysed strains, only 5 (3.1\%) were susceptible to all tested antimicrobials. No antimicrobial agent was efficient in inhibiting the growth of $100 \%$ of tested strains. Amoxicillin, ceftiofur, chloramphenicol, gentamicin and sulfamethoxazole with trimethoprim inhibited the growing of more than $90 \%$ of the strains. Ciprofloxacin and sulfafurazole were the antimicrobial agents that presented the significantly $(p<0.05)$ highest numbers of non-susceptible strains.

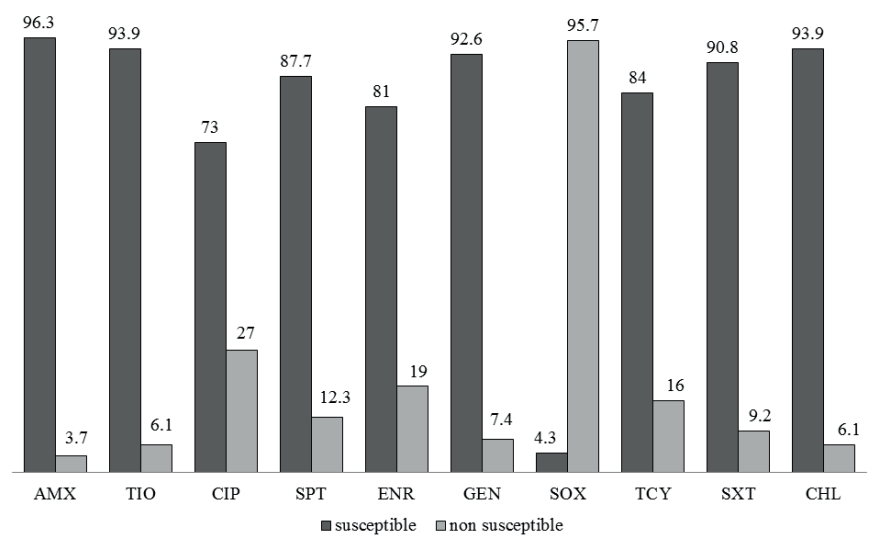

Figure 1 - Antimicrobial susceptibility (\%) of Salmonella strains to ten antimicrobial agents by disc diffusion tests, regardless of serotype.

There were important differences in antimicrobial resistance among Salmonella serotypes, as described in Table 1.S. Typhimurium, S. Bredeney, S. Schwarzengrund and S. Tennessee showed the highest overall resistance rates. However, this result can be influenced by the reduced number of samples of the three last serotypes. Statistical associations between each serotype and its resistance for specific antibiotics were determined considering only the serotypes S. Enteritidis, S. Heidelberg, S. Hadar and S. Typhimurium. Amoxicillin resistance was associated with $S$. Heidelberg, ciprofloxacin with $S$. Enteritidis and $S$. Typhimurium, spectinomycinwith $S$. Heidelberg 
Table 1 - Antimicrobial susceptibility and multiple antibiotic resistance (MAR) indices of Salmonella enterica serotypes isolated from poultry sources.

\begin{tabular}{|c|c|c|c|c|c|c|c|c|c|c|c|c|}
\hline \multirow{2}{*}{ Serotypes } & \multirow{2}{*}{$\begin{array}{l}\text { Total of } \\
\text { strains }\end{array}$} & \multicolumn{9}{|c|}{ Resistance (\%) } & \multirow{2}{*}{ Overall (\%) } & \multirow{2}{*}{$\begin{array}{c}\text { Average } \\
\text { MAR }\end{array}$} \\
\hline & & $\mathrm{TIO}$ & CIP & SPT & ENR & GEN & SOX & TCY & SXT & $\mathrm{CHL}$ & & \\
\hline S. Enteritidis & 70 & $6(8.6)$ & $26(37.1)$ & 0 & $16(22.9)$ & $8(11.4)$ & $65(92.9)$ & 0 & $1(1.4)$ & $1(1.4)$ & $123(17.6)$ & 0.18 \\
\hline S. Heidelberg & 49 & $3(6.1)$ & $11(22.4)$ & $4(8.2)$ & $10(20.4)$ & $2(4.1)$ & $47(95.9)$ & $2(4.1)$ & 0 & 0 & $79(16.1)$ & 0.17 \\
\hline S. Hadar & 14 & 0 & $1(7.1)$ & 0 & 0 & 0 & $14(100)$ & $14(100)$ & 0 & 0 & $29(20.7)$ & 0.21 \\
\hline S. Typhimurium & 8 & 0 & $5(62.5)$ & $5(62.5)$ & $4(50)$ & $2(25)$ & $8(100)$ & 7 (87.5) & $3(37.5)$ & $2(25)$ & $36(45)$ & 0.45 \\
\hline S. Bredeney & 5 & 0 & 0 & $5(100)$ & 0 & 0 & $5(100)$ & $1(20)$ & $5(100)$ & $4(80)$ & $20(40)$ & 0.40 \\
\hline S. Anatum & 5 & 0 & $1(20)$ & $2(40)$ & $1(20)$ & 0 & $5(100)$ & 0 & $2(40)$ & $1(20)$ & $12(24)$ & 0.26 \\
\hline S. Agona & 4 & $1(25)$ & 0 & 0 & 0 & 0 & $4(100)$ & 0 & 0 & 0 & $5(12.5)$ & 0.15 \\
\hline S. Tennessee & 3 & 0 & 0 & $2(66.7)$ & 0 & 0 & $3(100)$ & $2(66.7)$ & $2(66.7)$ & 0 & $9(30)$ & 0.45 \\
\hline S. Infantis & 2 & 0 & 0 & $1(50)$ & 0 & 0 & $2(100)$ & 0 & $1(50)$ & $1(50)$ & $5(25)$ & 0.25 \\
\hline S. Brandenburg & 2 & 0 & 0 & 0 & 0 & 0 & $2(100)$ & 0 & 0 & 0 & $2(10)$ & 0.10 \\
\hline S. Schwarzengrund & 1 & 0 & 0 & $1(100)$ & 0 & 0 & $1(100)$ & 0 & $1(100)$ & $1(100)$ & $4(40)$ & 0.40 \\
\hline
\end{tabular}

Legend: amoxicillin (AMX), ceftiofur (TIO), ciprofloxacin (CIP), chloramphenicol (CHL), enrofloxacin (ENR), gentamicin (GEN), spectinomycin (SPT), sulfafurazole (SOX), sulfamethoxazolewithtrimethoprim (SXT) andtetracycline (TET).

and S. Typhimurium, sulfafurazole withS. Enteritidis, tetracycline with S. Hadar and S. Heidelberg, and chloramphenicol and sulfamethoxazole with trimethoprim with $S$. Typhimurium.

The maximum and minimum MAR indices of isolates were 0.1 and 0.6 , respectively, and the average MAR was 0.2. The MAR distribution according to serotype is described in Table 1.Approximately 18\% (30/163) of Salmonella strains were classified as MDR strains. The majority of MDR strains belonged to the serotypes S. Enteritidis (9/30), S. Typhimurium (7/30) and S. Bredeney (5/30).

\section{Detection of virulence-associated genes}

Most of the investigated genes presented a high frequency and a regular distribution regardless of the serotype. The frequencies for the twenty-six genes are described according to serotype in Table 2. Serotype $S$. Enteritidis presented the highest average (24) number of detected genes (of the 26 virulence-associated genes analysed), followed by S. Heidelberg (21), S. Typhimurium (21), S. Infantis (21), S. Hadar (20) and S. Tennessee (20).

For statistical analyses of the association between a given gene and serotypes, only $S$. Enteritidis, $S$. Heidelberg, S. Hadar and S. Typhimurium were used in the comparison because they had the highest numbers of samples. Eight genes were positively associated $(p<0.05)$ with at least one serotype, and one gene was negatively associated $(p<0.05)$ with the four serotypes. This negative association indicates that this gene was restricted to some groups of strains and was not usually related to one of the four analysed serotypes. Based on the distribution of virulence-associated genesin these serotypes, a decision tree was constructed (Figure 2) considering the sefA, sopE and IpfA genes.

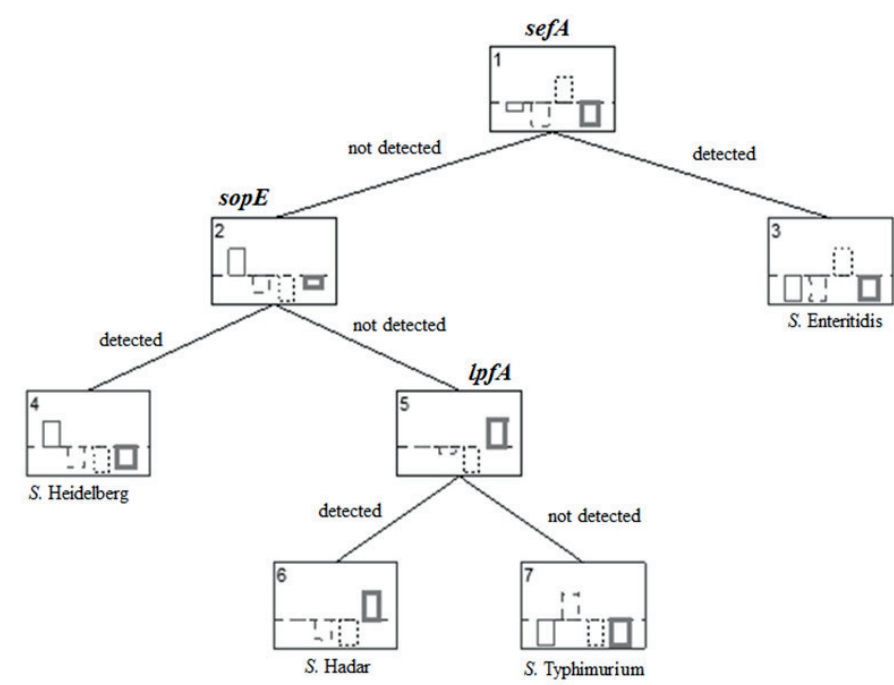

Figure 2 - Classification tree of S. Enteritidis, S. Heidelberg, S. Hadar and S. Typhimurium based on the distribution of sefA, sopE and IpfA genes.

\section{DISCUSSION}

Salmonella spp. are considered priority bacteria by the World Health Organization (WHO) and the World Organisation for Animal Health (OIE) in monitoring the emergence of resistant strains in animals due to the increase in their antimicrobial resistance over the years. Thus, in vitro tests are important not only for the choice of antimicrobial for the treatment of infections but also for the monitoring of resistance (Jorgensen \& Ferraro, 2009). Unfortunately, Brazil does not have integrated programmes for monitoring the antimicrobial resistance of the main pathogens of humans and production animals, such as Salmonella spp. and Campylobacter jejuni. The analysis of the behaviour of these pathogens in these populations would allow the adoption of new measures to control and restrict the use of antimicrobials. 


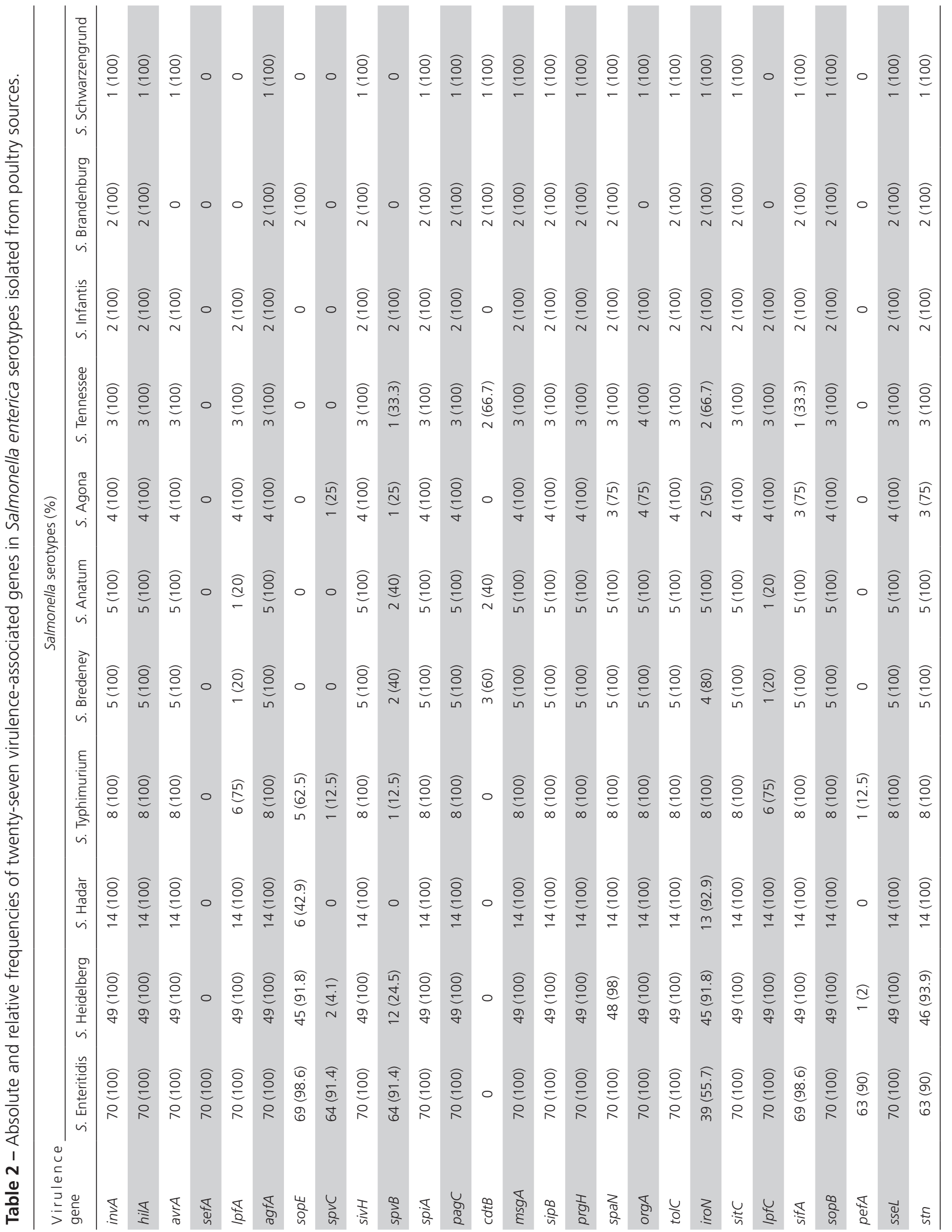


Borges KA, Furian TQ, Souza SN, Salle CTP, Moraes HLS, Nascimento VP

\section{Antimicrobial Resistance and Molecular Characterization of Salmonella Enterica Serotypes Isolated from Poultry Sources in Brazil}

Resistance to sulfonamides is common in production animals, and it has been widely described in the literature (Benacer et al., 2010; World Health Organization, 2011a; Proroga et al., 2015; European Food Safety Authority 2017a). These high rates of resistance are possibly related to the wide use of these substances, which would result in an increase in selective pressure (Grave et al., 2010; Mąka et al. 2015; Food and Drug Administration, 2017). More than 70\% of the strains resistant to ciprofloxacin also showed resistance to enrofloxacin. This fact can be explained by the similar structures of these antimicrobials (Marshall \& Levy, 2011). Fluoroquinolones are considered the preferred antimicrobial agents for the treatment of salmonellosis in humans (World Health Organization, 2011b; European Food Safety Authority, 2017a). The WHO classifies these antimicrobials as extremely important and recommends special attention be paid to the surveillance of antimicrobial resistance in animals, as resistance may be the result of the transfer of strains from non-human sources. The WHO also supports the interruption or the reduction of their use in production animals (World Health Organization, 2011a).

Official data show that the potential for antimicrobial resistance acquisition may vary among serotypes (Canadian Integrated Program for Antimicrobial Resistance Surveillance, 2013; Centers for Disease Control, 2015; European Food Safety Authority, 2017a). Thus, the relative contribution of each serovar may also influence the overall level of resistance in the genus Salmonella (European Food Safety Authority, 2015). S. Typhimurium strains presented the highest overall resistance, and almost all strains were classified as MDR in our study. This serotype has shown high resistance rates to the most commonly used drugs, regardless of the source of isolation (Ahmed et al., 2016; Almeida et al., 2016; Lopes et al., 2016; Wang et al., 2017). Recently, S. Heidelberg strains have become more resistant to antibiotics, limiting therapeutic options (Center for Infectious Disease Research and Policy, 2017). In addition, the frequency of finding MDR S. Heidelberg has increased dramatically in the last few years (Centers for Disease Control, 2014). However, our strains did not present a higher frequency of multidrug resistance.

Although the frequency of MDR strains found in this study was lower than previously reported frequencies (Pulido-Landínez et al., 2014; Proroga et al., 2015), these results indicate that the increase in antimicrobial resistance is a matter of worldwide concern, even though there are differences between the methodologies used (Lertworapreechaet al., 2013). Almost all strains of $S$. Typhimurium, frequently isolated from human salmonellosis, were classified as MDR, which is of great concern to public health.

Although there is evidence that the use of antimicrobials in production animals is responsible for resistance in human to some pathogens such as Salmonella spp., control has not been effectively adopted in all sectors of the poultry production chain (World Health Organization, 2011a; World Health Organization, 2011b; Collignon, 2012). In addition, globalization and the consequent trade in animal products between countries allow MDR strains to be disseminated to different regions (World Health Organization, 2011b; European Food Safety Authority, 2015). Some factors such as foreign travel, international trade in food, the breeding of different species in the same environment and the vertical structure of some animal production systems may also influence the propagation of resistant strains (European Food Safety Authority, 2015).

The presence of the sefA gene was restricted to $S$. Enteritidis, since the gene had positive association $(p<0.05)$ with this serovar and negative association $(p<0.05)$ with the others. This gene is a marker of this serotype (Amini et al., 2010). A positive association $(p<0.05)$ of IpfA and IpfC with $S$. Enteritidis, $S$. Heidelberg and $S$. Hadar serotypes was also observed, demonstrating that despite being considered conserved within the genus Salmonella (Bäumler \& Heffron, 1995; Doran et al., 1996), the operon IpfABCDE is more frequent in some serotypes. The plasmidial genes $s p v B$, spvCand pefA were positively associated $(p<0.05)$ with $S$. Enteritidis. A negative association $(p<0.05)$ between these genes and the serotypes $S$. Hadar and $S$. Heidelberg was also found. According to Rychlik et al. (2009), S. Enteritidis and S. Typhimurium tend to present plasmids, whereas other serotypes such as $S$. Typhi, S. Hadar and S. Infantis usually do not. The sopE gene is positively associated $(p<0.05)$ with $S$. Enteritidis and $S$. Heidelberg. The frequency variation of this gene among Salmonella serotypes may be related to its location, since it is found in a bacteriophage. Phage have predilections for certain serotypes, and they facilitate the horizontal transmission of bacterial genes (Mirold et al., 1999). The iroN gene showed a positive association $(p<0.05)$ with $S$. Typhimurium, $S$. Heidelberg and $S$. Hadar and a negative association $(p<0.05)$ with $S$. Enteritidis. This result differs from the results published by Skyberg et al.(2006), which 
Borges KA, Furian TQ, Souza SN, Salle CTP, Moraes HLS, Nascimento VP

\section{Antimicrobial Resistance and Molecular Characterization of Salmonella Enterica Serotypes Isolated from Poultry Sources in Brazil}

indicated that the gene would be distributed equally among the different Salmonella serotypes.

A decision tree computes binary classifications based on univariate divisions of categorical predictors. It finds the best data partition and discards variables that do not fully explain the categories of the variable response. In this context, classification trees are useful in determining serotype marker genes. In our study, sefA, sopE and IpfA are potentially markers for $S$. Enteritidis, $S$. Typhimurium, $S$. Heidelberg and S. Hadar. Although sopE and IpfA may be present in all serotypes and sefA is exclusively detected in $S$. Enteritidis, simultaneous analysis of the presence or absence of these genes through the construction of decision trees can significantly predict the probable involved serotype.

The observed association between antimicrobial resistance and specific serotypes is useful in developing specific control and treatment measures for each serotype. Despite the virulence genes being evenly distributed among the serotypes, some of these genes are associated with specific serotypes. Further studies are needed to understand how the molecular patterns of each serotype influence pathogenicity and virulence in vivo. In addition, sefA, sopE and IpfA are possible markers of Salmonella serotypes.

\section{ACKNOWLEDGEMENTS}

This work was supported by the Brazilian National Council of Technological and Scientific Development CNPq [grant number 476092/2013-2].

\section{REFERENCES}

Ahmed HA, El-Hofy Fl, Shafik SM, Abdelrahman MA, Elsaid GA. Characterization of virulence-associated genes, antimicrobial resistance genes, and Class 1 integrons in Salmonella enterica serovar typhimurium isolates from chicken meat and humans in Egypt. Foodborne Pathogens and Disease 2016;13(6):281-288.

Almeida F, Medeiros MIC, Kich JD, Falcão JP. Virulence-associated genes, antimicrobial resistance and molecular typing of salmonella typhimurium strains isolated from swine from 2000 to 2012 in Brazil. Journal of Applied Microbiology 2016;120(6):1677-1690.

Alvarez NM. Virulencia, Resistência y elementos genéticos móviles em serotipos no prevalentes de Salmonella enterica [dissertation]. Oviedo (ES): Universidad de Oviedo; 2007

Amini K, Salehi TZ, Nikbakht G, Ranjbar R, Amini J, Ashrafganjooei SB. Molecular detection of invA and spv virulence genes in Salmonella enteritidis isolated from human and Inimals in Iran. African Journal of Microbiology Research 2010;4(21):2202-2210.

Bäumler AJ, Heffron F. Identification and sequence analysis of IpfABCDE, a putative fimbrial operon of Salmonella Typhimurium. Journal of Bacteriology 1995;177(8):2087-2097.
Benacer D, Thong KL, Watanabe H, Puthucheary SD. Characterization of drug resistant Salmonella enterica serotype Typhimurium by antibiograms, plasmids, integrons, resistance genes and PFGE. Journal of Microbiology and Biotechnology 2010;20(6):1042-1052.

Borges KA, Furian TQ, de Souza SN, Menezes R, Salle CTP, de Souza Moraes $\mathrm{HL}$, et al. Phenotypic and molecular characterization of Salmonellaenteritidis SE86 isolated from poultry and salmonellosis outbreaks. Foodborne Pathogens and Disease 2017b;14(12):742-754.

Borges KA, Furian TQ, de Souza SN, Tondo EC, Streck AF, Salle CTP, et al. Spread of a major clone of Salmonella enterica serotype Enteritidis in poultry and in salmonellosis outbreaks in Southern Brazil. Journal of Food Protection 2017a;80(1):158-163.

Brasil. Agência Nacional de Vigilância Sanitária. Relatório do monitoramento da prevalência e do perfil de suscetibilidade aos antimicrobianos em enterococos e salmonelas isolados de carcaças de frangos congeladas comercializadas no Brasil. Brasília: Programa Nacional de Monitoramento da Prevalência e da Resistência Bacteriana em Frangos; 2008. p. 188

Brasil. Agência Nacional de Vigilância Sanitária. Monitoramento da prevalência e do perfil de suscetibilidade aos antimicrobianos em enterococos e salmonelas isolados de carcaças de frangos congeladas comercializadas no Brasil. Brasília: Programa Nacional de Monitoramento da Prevalência e da Resistência Bacteriana em Frangos; 2012. p. 171

Brasil. Ministério da Saúde - Secretaria de Vigilância em Saúde. Doenças transmitidas por alimentos [cited 2018 Apr 10]. Brasil: Ministério da Saúde - Secretaria de Vigilância em Saúde; 2018. Disponível em: http://portalarquivos2.saude.gov.br/images/pdf/2018/janeiro/17/ Apresentacao-Surtos-DTA-2018.pdf.

Canadian Integrated Program for Antimicrobial Resistance Surveillance. Annual report- antimicrobial tesistance. Ottawa: Public Health Agency of Canada; 2013.

Capalonga R, Ramos RC, Both JMC, Soeiro MLT, Longaray SM, Haas S, et al. Salmonella serotypes, resistance patterns, and food vehicles of salmonellosis in Southern Brazil between 2007 and 2012. Journal of Infection in Developing Countries 2014;8(7):811-817.

Centers for Disease Control. Multistate outbreak of multidrug-resistant Salmonella Heidelberg infections linked to foster farms brand chicken (final update) [cited 2017 Dec 4]. Centers for Disease Control; 2014 Available from: https://www.cdc.gov/salmonella/heidelberg-10-13/.

Centers for Disease Control. Surveillance for foodborne disease outbreaks United States, 2015: annual report [cited 2018 Feb 5]. Atlanta; 2015. Available from: https://www.cdc.gov/foodsafety/ pdfs/2015FoodBorneOutbreaks_508.pdf/.

Center for Infectious Disease Research and Policy. New resistance gene found in salmonella isolated from chickens [cited 2018 Apr 24]. Minneapolis: CIDRAP; 2017. Disponível em: http://www.cidrap. umn.edu/news-perspective/2017/05/new-resistance-gene-foundsalmonella-isolated-chickens.

Clinical and Laboratorial Standards Institute. Performance standards for antimicrobial susceptibility tests for bacteria isolated from animals. Clinical and Laboratorial Standards Institute 2014a;33(3):94.

Clinical and Laboratorial Standards Institute. Performance standards for antimicrobial susceptibility tests for bacteria isolated from animalssecond information supplement. Clinical and Laboratorial Standards Institute 2014b;33(3):74.

Clinical and Laboratorial Standards Institute. Performance standards for antimicrobial susceptibility testing; twenty-sixth informational supplement M100-S26. Wayne, PA: CLSI; 2016. 
Clouthier SC, Müller KH, Doran JL, Collinson SK, Kay WW. Characterization of three fimbrial genes, SefABC, of Salmonella enteritidis. Journal of Bacteriology 1993;175(9):2523-2533.

Collignon P. Antibiotic resistance in human Salmonella isolates are related to animal strains. Proceedings. Biological Sciences2012;279(1740):2922-2923.

DeJong HK, Parry CM, van der PollT, Wiersinga WJ. Host-pathogen interaction in invasive Salmonellosis. PLOS Pathogens 2012;8(10):e1002933.

Doran JL, Collinson SK, Clouthier SC, Cebula TA, Koch WH, Burian J, et al. Diagnostic potential of sefA DNA probes to SalmonellaEnteritidis and certain other O-Serogroup D1 Salmonella serovars. Molecular and Cellular Probes 1996;10(4):233-246.

European Food Safety Authority. EU summary report on antimicrobial resistance in zoonotic and indicator bacteria from humans, animals and food in 2013. EFSA Journal 2015;13(2):1-178.

European Food Safety Authority. EU summary report on antimicrobial resistance in zoonotic and indicator bacteria from humans, animals and food in 2016. EFSA Journal 2017a;15:1-212.

European Food Safety Authority. The European union summary report on trends and sources of zoonoses, zoonotic agents and food-borne outbreaks in 2016. EFSA Journal 2017b;15(12):1-228.

Foley SL, Lynne AM. Food animal-associated Salmonella challenges: pathogenicity and antimicrobial resistance. Journal of Animal Science 2008;86(14 Suppl):E173-187.

Food and Drug Administration. 2013 summary report on antimicrobials sold or distributed for use in food-producing animals. Maryland: FDA: Department of Health and Human Services; 2014. p 57.

Food and Drug Administration. 2016 summary report on antimicrobials sold or distributed for use in food-producing animals. Maryland: FDA: Department of Health and Human Services; 2017. p 67

Grave K, Torren-Edo J, Mackay D. Comparison of the sales of veterinary antibacterial agents between 10 European countries. Journal of Antimicrobial Chemotherapy 2010;65(9):2037-2040.

Hacker J, Carniel E. Ecological fitness, genomic islands and bacterial pathogenicity. A Darwinian view of the evolution of microbes. EMBO Reports 2001;2(5):376-381.

Jorgensen $\mathrm{JH}$, Ferraro MJ. Antimicrobial susceptibility testing: a review of general principles and contemporary practices. Clinical Infectious Diseases 2009;49(11):1749-1755

Koluman A, Dikici A. Antimicrobial resistance of emerging foodborne pathogens: status quo and global trends. Critical Reviews in Microbiology 2013;39(1):57-69

Krumperman $\mathrm{PH}$. Multiple antibiotic resistance indexing of Escherichia coli to identify high-risk sources of fecal contamination of foods. Applied and Environmental Microbiology 1983;46(1):165-170.

Lertworapreecha M, Sutthimusik S, Tontikapong K. Antimicrobial resistance in Salmonella enterica isolated from pork, chicken, and vegetables in Southern Thailand. Jundishapur Journal of Microbiology 2013;6(1):3641

Lopes GV, Michael GB, Cardoso M, Schwarz S. Antimicrobial resistance and Class 1 integron-associated gene cassettes in Salmonella entericaserovar Typhimurium isolated from pigs at slaughter and abattoir environment. Veterinary Microbiology2016;194:84-92.

Madigan MT, Martinko JM, Dunlap PL, Clark DP. Microbiologia de brock. Porto Alegre: Artmed; 2010.
Mąka Ł, Maćkiw E, Ścieżyńska H, Modzelewska M, Popowska M. Resistance to sulfonamides and dissemination of sul genes among Salmonella spp. Isolated from food in Poland. Foodborne Pathogens and Disease 2015;12(5):383-389.

Marshall BM, Levy SB. Food animals and antimicrobials: impacts on human health. Clinical Microbiology Reviews 2011;24(4):718-733.

Mirold S, Rabsch W, Rohde M, Stender S, Tschäpe H, Rüssmann H, et al. Isolation of a temperate bacteriophage encoding the Type III effector protein sope from an epidemic Salmonella Typhimurium strain. Proceedings of the National Academy of Sciences of the United States of America 1999;96(17):9845-9850.

National Antimicrobial Resistance Monitoring System for Enteric Bacteria. Atlanta: CDC; 2017. p.14.

Proroga YTR, Capuano F, Carullo MR, La Tela I, Capparelli R, Barco L, et al. Occurrence and antimicrobial resistance of Salmonella strains from food of animal origin in Southern Italy. Folia Microbiológica 2016;61(1):21-27.

Pulido-Landínez M, Washington P, Thornton JK, Zhang Y, Sánchez-Ingunza $R$, Banda $A$, et al. Serotype and antimicrobial resistance patterns of Salmonella isolates from commercial birds and poultry environment in Mississippi. Avian Diseases 2014;58(1):64-70.

Robinsom S. The big five: most common Salmonella strains in food borne illness outbreaks [cited 2017 Nov 6]. Washington: Food Saftey News; 2013. Available from: http://www.foodsafetynews.com/2013/08/thefive-most-common-salmonella-strains/\#.UsbJ5dJDunl.

Rychlik I, Karasova D, Sebkova A, Volf J, Sisak F, Havlickova H, et al. Virulence potential of five major pathogenicity islands (SPI-1 to SPI-5) of Salmonella enterica serovar enteritidis for chickens. BMC Microbiology 2009;9(1):268.

Schwarz S, Silley P, Simjee S, Woodford N, van Duijkeren E, Johnson AP, et al. Editorial: assessing the antimicrobial susceptibility of bacteria obtained from animals. Journal of Antimicrobial Chemotherapy 2010;65(4):601-604

Skyberg JA, Logue CM, Nolan LK. Virulence genotyping of Salmonella spp. with multiplex PCR. Avian Diseases 2006;50(1):77-81

Tondo EC, Ritter AC. Salmonella and salmonellosis in Southern Brazil: a review of the last decade. In: Montes AS, Santos PE, editors. Salmonella: classification, genetics and disease outbreaks. New York: Nova Science Publishers; 2012. p. 175-191.

Wallis TS, Galyov EE. Molecular basis of Salmonella-induced enteritis Molecular Microbiology 2000;36(5):997-1005.

Wang H, Ye K, Wei X, Cao J, Xu X, Zhou G. Occurrence, antimicrobial resistance and biofilm formation of Salmonella isolates from a chicken slaughter plant in China. Food Control 2013;33(2):378-384.

Wang J, Li Y, Xu X, Liang B, Wu F, Yang X, et al. Antimicrobial resistance of Salmonella entericaserovar typhimurium in Shanghai, China. Frontiers in Microbiology 2017;8:510.

Wisner A, Desin T, White A, Potter A, Köster W. The Salmonella pathogenicity Island-1 and -2 encoded Type III secretion systems. In: Kumar Y, editor. Salmonella - a diversified superbug. Croatia: Intech; 2012. p.469-494.

World Health Organization. Critically important antimicrobials for human medicine. Geneva: WHO; 2011a.

World Health Organization. Tackling antibiotic resistance from a food safety perspective in Europe. Geneva: WHO; $2011 \mathrm{~b}$ 